TITLE:

\title{
NOTODELPHYID COPEPODS ASSOCIATED WITH COMPOUND ASCIDIANS IN AKKESHI BAY, JAPAN
}

AUTHOR(S):

Ooishi, Shigeko

\section{CITATION:}

Ooishi, Shigeko. NOTODELPHYID COPEPODS ASSOCIATED WITH COMPOUND ASCIDIANS IN AKKESHI BAY, JAPAN. PUBLICATIONS OF THE SETO MARINE BIOLOGICAL LABORATORY 1972, 19(5): 303-325

ISSUE DATE:

1972-03-08

URL:

http://hdl.handle.net/2433/175727

RIGHT: 


\title{
NOTODELPHYID COPEPODS ASSOCIATED WITH COMPOUND ASCIDIANS IN AKKESHI BAY, JAPAN
}

\author{
SHIGEko OOISHI \\ Faculty of Fisheries, Prefectural University of Mie, Tsu, Japan
}

With Plate XIV, 1 Map and 10 Text-figures

The notodelphyid copepods living in compound ascidians are characterized generally by the possession of inflated, or vermiform bodies and by various degrees of degeneration in their appendages. After the useful key to distinguish the 13 species then known was given by Dudley and Solomon (1966, p. 319), the number has gradually been increasing, but they are not as well known as the notodelphyids found in simple ascidians. Twenty three species of them covering 14 genera (Table 1) are now known, while in the latter group, having simpler structural modification, there are five times more species known than in the former group. Host association of the genera is not necessarily restricted to compound ascidians, since Prophioseides brevis STOck, 1967 inhabits a solitary ascidian and Thoracodelphys uniseta STock and Humes, 1970 and Demoixys affinis STOck and Humes, 1970 were reported from an octocoral.

Table 1. Notodelphyids inhabiting compound ascidians (except for the present notodelphyids).

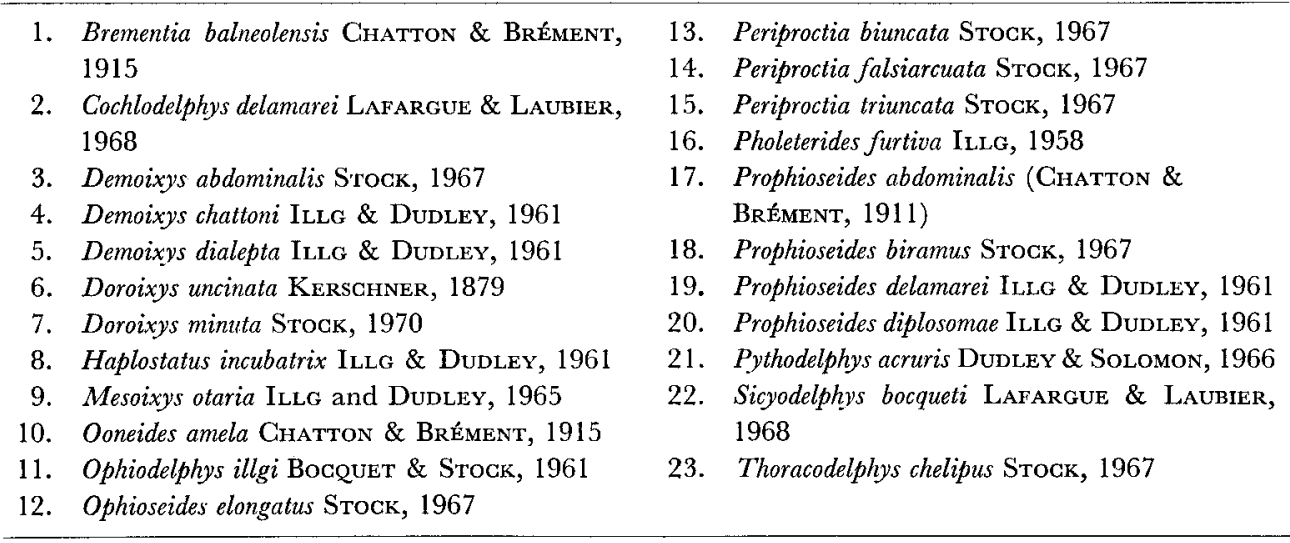

Publ. Seto Mar. Biol. Lab., XIX (5), 303-325, 1972. (Article 21) 
From the geographic point of view, Pholeterides furtiva ILLG, 1958 and Pythodelphys acruris Dudley and Solomon, 1966 are Pacific species, while the other 21 species are found in the waters surrounding Europe, the Red Sea and the Atlantic Ocean. Three copepods described below, Doroixys uncinata Kerschner, 1879, Prophioseides ampullacea n. sp., and Demoixys fusiforma n. sp., are notodelphyids newly found in compound ascidians from the Pacific.

Eight species of examined compound ascidians were collected in Akkeshi Bay, Hokkaido, Japan, during October 7-28, 1968 (Table 2). Of them Amaroucium glabrum Verrill, 1871, Diplosoma mitsukurii Oka, 1892 and Distaplia dubia (OkA), 1927 are the hosts of the present notodelphyids. The first and last ascidians are also the hosts for ascidicolids (in the broad sense of SchellenberG), carrying egg sacs instead of brood pouches. The ascidicolids are to be dealt with in a future paper.

Table 2. Compound ascidians and their copepod associates in Akkeshi Bay

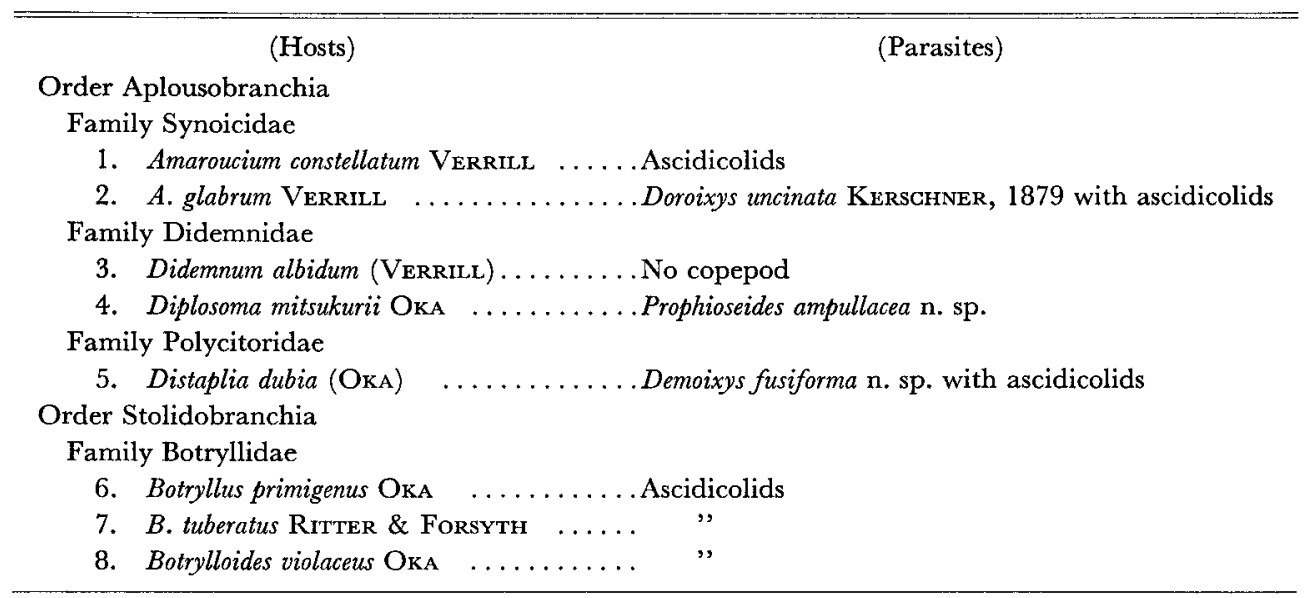

Ascidian colonies removed from the stems of seaweeds (mainly Sargassum spp.) were examined under a dissecting microscope at the Akkeshi Marine Biological Station, Hokkaido University, $43^{\circ} 00^{\prime} \mathrm{N}$ and $144^{\circ} 50^{\prime} \mathrm{E}$, to collect the parasites. The best specimens of the parasites were depicted and color pictures were taken. All of the materials were fixed with absolute alcohol then preserved in $70 \%$ alcohol for further work. Dissection was mostly done in lactic acid.

I wish to thank Dr. Takasi Tokioka of the Seto Marine Biological Laboratory for taking much trouble in identifing ascidians. I am indebted to Director Dr. Yasuhiko Kano and Mr. Katsuhiko SAwavanr of the Akkeshi Marine Biological Station for their kindness in allowing me the use of Laboratory facilities and their assistance in collecting the material. I am also indebted to Dr. Sueo M. SHinNo of the Prefectural University of Mie, Dr. Paul L. ILlg of the University of Washington, Dr. Katsuma DaN of Tokyo Metropolitan University and Dr. Mayumi Yamada of Hokkaido Uni- 


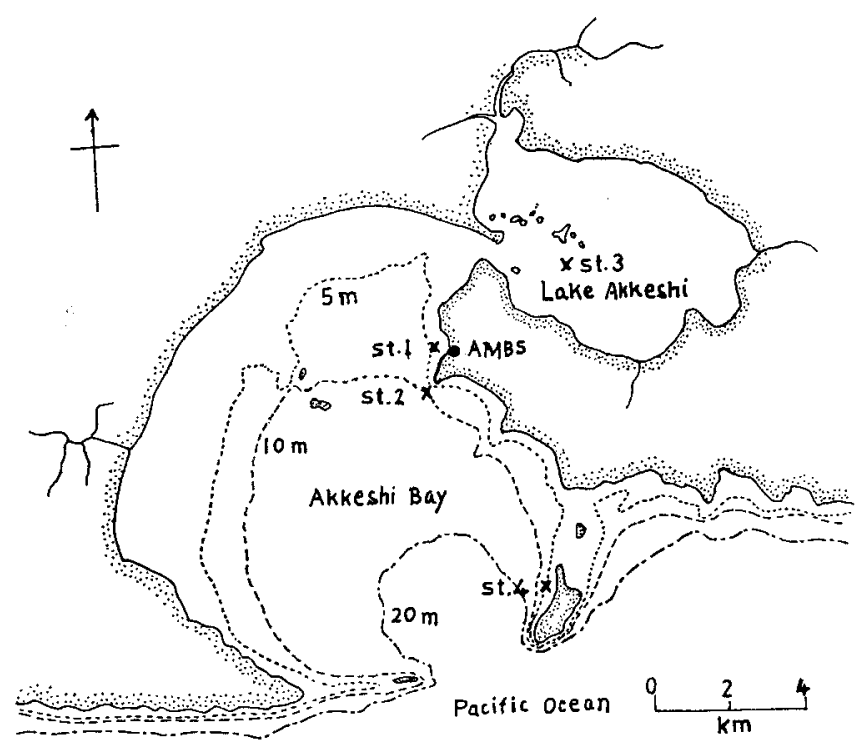

Map 1. Map of Akkeshi Bay (after UaHida et al., 1963) and the stations of collection (1-4).

versity for their great help and assistance that brought this work into completion. The study was aided by a research grant (No. 4093) from the Ministry of Education of the Japanese Government.

\section{Doroixys uncinata KeRSCHNER, 1879}

\section{(Text-figs. 1-3; Pl. XIV, 2)}

References: Kerschner (1879, pp. 176-179, pl. 4, figs. 11-13, pl. 5, figs. 1-12) ; Canu (1892, pp. 8385, 202, pl. 14, figs. 1-14, pl. 15, figs. 1-11); I11g (1958, pp. 484, 485); I11g and DudLeY (1965, pp. 376, 447); Dudley and Solomon (1966, pp. 314, 319); Stock (1970, pp. 13-16, figs. 10-13).

Specimens examined: From test of Amaroucium glabrum Verrill (Pl. XIV, Fig. 1), attached to stems of Sargassum, Akkeshi Bay, dredged in depth of 2-5 m, 2 ㅇ (St. 2, October 9), 2 ㅇ (St. 2, October 14), 8ㅇ (St. 1, October 28), i. e., 12 females in all, inclusive of 1 holotype and 11 paratypes.

Description: Female (Figs. 1-3 and Pl. XIV, Fig. 2) : Body (Fig. 1, a) relatively small, compressed, and with 3 major divisions (cephalosome, metasome and urosome) well defined. In living state slightly curved in metasomal region while in fixed specimen urosome curved downward almost at a right angle. Total length measured from anteriormost on cephalosome to end of urosome $0.932 \mathrm{~mm}$. Body white, transparent, with reddish eye and brownish gut. Cephalosome protruded at postero-lateral corner into a pointed process on each side and bearing appendages up to maxillipeds (Fig. 1, e). Rostrum (Figs. 1, e and 2, f) large, long and triangular in shape having two sides 1.2 times as long as base. Metasome distinctly 4-segmented; first 3 segments 

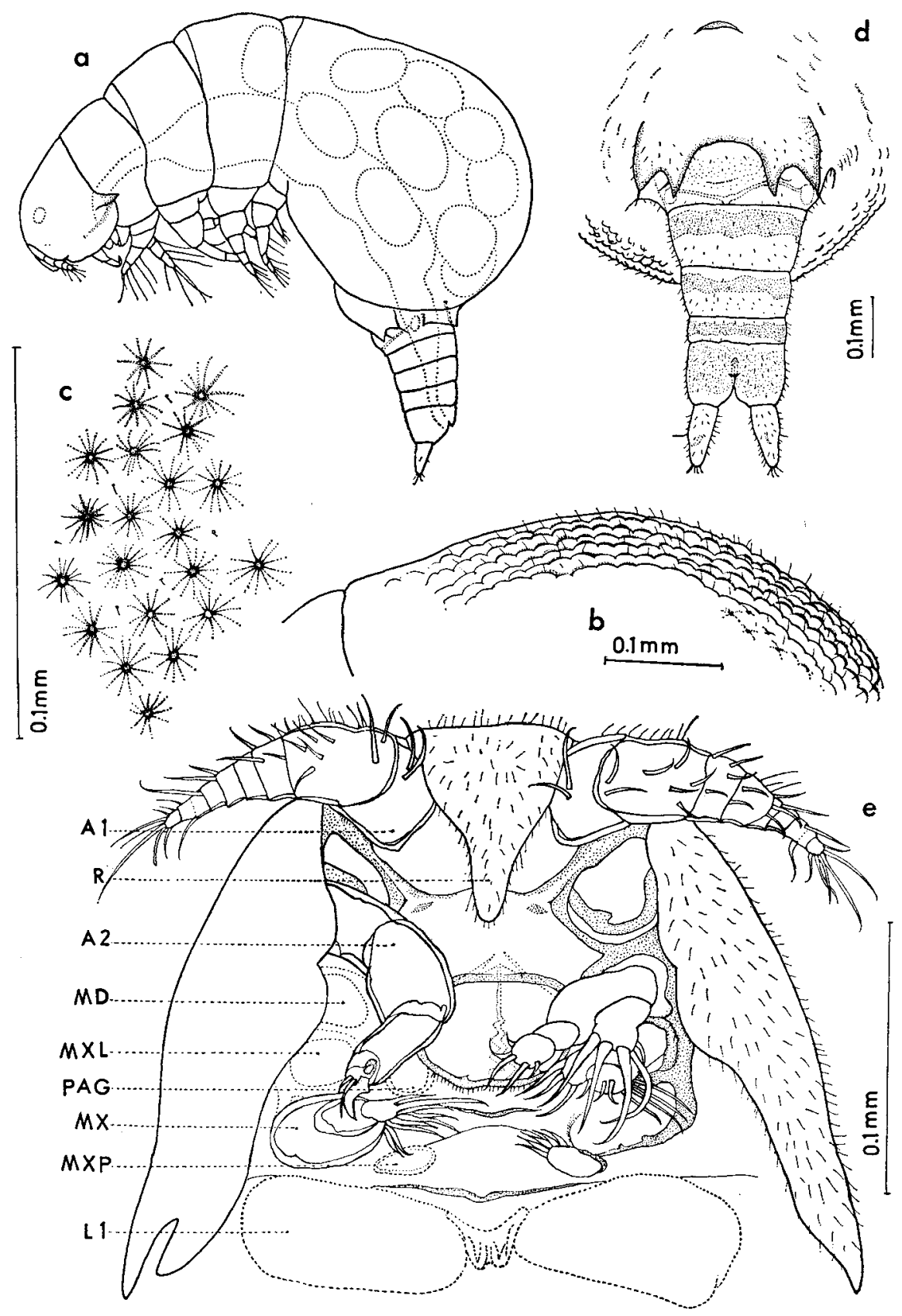

Fig. 1. Doroixys uncinata Kerschner, female: a, lateral view; b, integument of 4th metasomal segment, left side view; $c$, same, upper side view; d, urosome, ventral view; e, oral area. 
of relatively moderate size, whereas last one posteriorly inflated to enclose a brood pouch. However, brood pouch seems extended to second or third segments. Embryos in incubatory pouch of relatively large size, brown in color and usually 10-16 in number. Urosome (Figs. 1, d and 3, r, s) 5-segmented. Dorsal side of first segment constricted from metasome but constricted area covered by posterior extension of metasome, and lateral side of segment coalesced with metasome to form opening of incubatory pouch as a wide slit on dorsal side. Terminal end of metasome on ventral side (Fig. 1, d) bearing bilobed fifth legs united midventrally and basally, articulating on first urosomal segment. Therefore, articulation between metasome and urosome only found clearly at middle of base of united fifth legs. Ventral side of first urosomal segment provided with genital apparatus, consisting of central vulval opening and diversing sclerotized seminal tubes which end in seminal vescles located on sides. Moreover, dorsal side of segment with broad plate-like sclerotization. Remaining 4 segments each surrounded by characteristic and partially sclerotized coating. Anal segment bearing small caudal rami, each ending in a blunt tip. Anal operculum triangular, well-defined. Body wall covered with minute cuticular hairs. Integument of fourth metasomal segment shows sculptures formed by many small crater-like pits (Fig. 1, b, c).

Antennule (Fig. 2, g) 8-segmented, gradually tapering distally. Two proximal segments expanded, larger than rest. Sclerotized coating covering each segment. Proportional lengths of segments from first to eighth: $4.5: 6: 2.3: 1: 1: 0.9: 1.2: 1$. Seventh segment appearing to comprise 2 subsegments. Setal armature indistinguishable from tiny hairs covering general surface of antennule.

Antenna (Fig. 2, h) 3-segmented. Proportional lengths of segments from basal to apical: $4: 5.2: 5.2$. Basal 2 segments unarmed, though heavily sclerotized on margins. Terminal segment with 1 short seta at about middle of outer margin, 1 curved hook and 2 short setae at apex.

Mandible (Fig. 2, i) with coxa bearing obscurely segmented flap. Medio-distal margin of coxa cut into 5 teeth graded in size, a row of closely set tiny ones and a proximal spinule. Basis obscurely articulated with rami and bearing 1 seta about halfway on medial margin. Endopod bearing 1 medial seta on poorely defined proximal segment, 2 medial and 3 terminal setae on distal segment. Unarticulated exopod with 5 long setae on terminal margin. All setae plumose.

Paragnath (Figs. 1, e and 2, j) located much medial to bases of mouthpart series, close to mouth and more or less opposite base of maxillule; consisting of sclerotized, thumb-like lobe, with fine hairs on medial margin.

Maxillule (Fig. 2, k) composed of obscurely 2-segmented protopod and unsegmented rami. Epipod represented by 1 stout seta. Coxa bearing 8 setae on medial margin, 6 of them non-plumose. Basis with 1 seta at medio-distal corner. Endopod and exopod provided with 3 short and 4 long setae respectively. Setae on rami all plumose. 


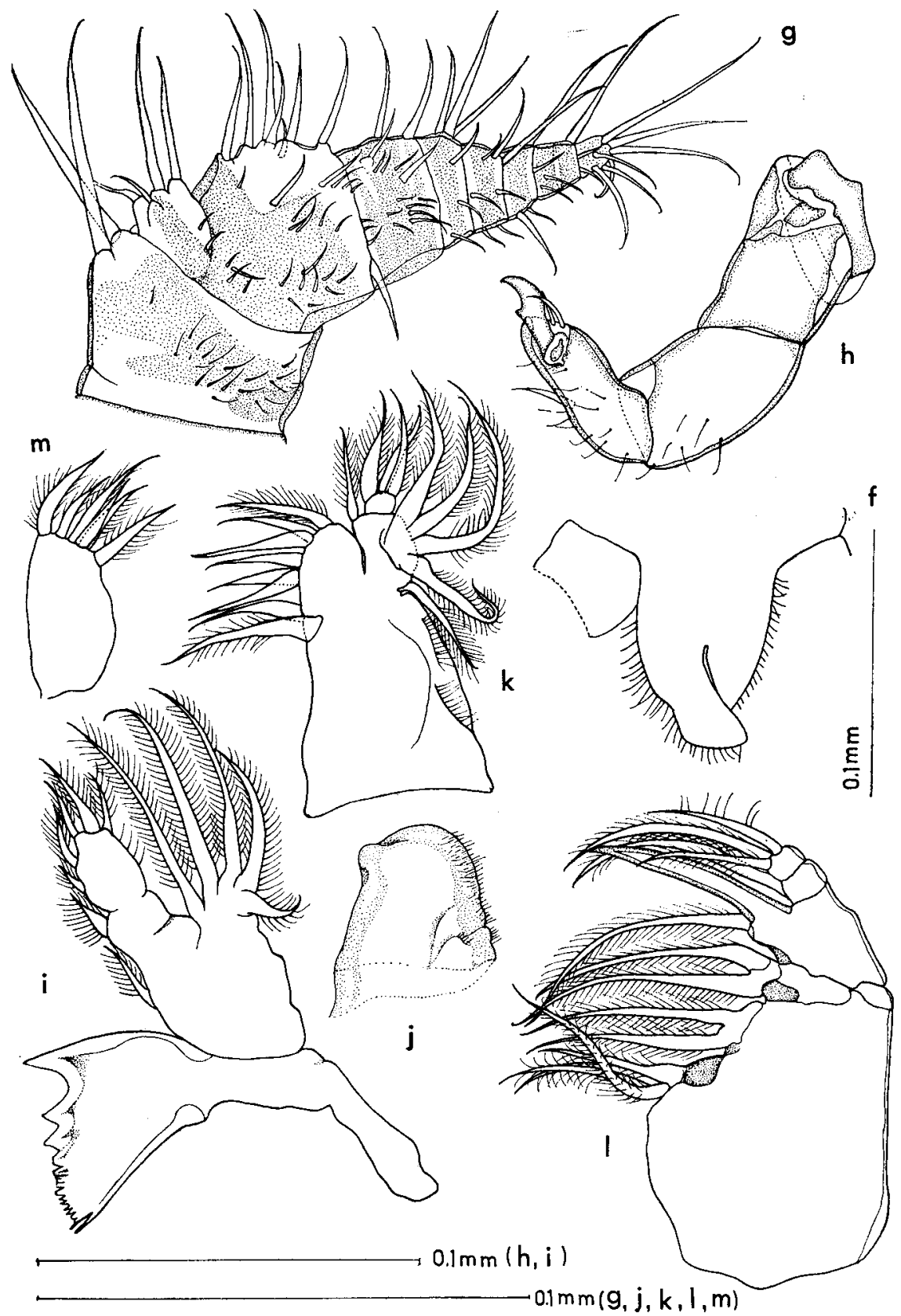

Fig. 2. Doroixys uncinata Kerschner, female: f, rostrum, posterior view; g, antennule; h, antenna; $i$, mandible; $j$, paragnath, left, antero-lateral view; $k$, maxillule, left, posterior view; l, maxilla, left, posterior view; $m$, maxilliped, left, anterior view. 
Maxilla (Fig. 2, 1) 4-segmented, broader basally, attenuated toward tip. Basal segment occupying more than half of entire length, bearing 3 endites respectively fringed with 4, 2 and 2 long medial setae. Second segment produced medially into 1 long, heavy, falcate process, from whose base 1 long seta arises. Third segment subrectangular, with 1 long medial seta. Fourth segment bearing 1 long and 2 short terminal setae. All setae plumose.

Maxilliped (Fig. 2, m) reduced to simple lobe, with 6 short plumose setae.

First leg (Fig. 3, n) comprised of 2-segmented protopod and 3-segmented rami of unequal length. Intercoxal plate subtriangular. Basis provided with 1 small spine at medio-distal corner and 1 setule on lateral margin. Endopod slightly longer than exopod, and armed with 9 setae in all: 1 medial seta on each of first 2 segments; 1 lateral, 2 terminal and 4 medial setae on terminal segment. Exopod with 2 spines and 9 setae in all: 1 stout lateral spine and 1 medial seta on basal segment; 1 small lateral spine and 1 medial seta on second segment; 2 lateral, 2 terminal and 3 medial setae on terminal segment. All setae plumose.

Second leg (Fig. 3, o) with 2-segmented protopod and 3-segmented rami of unequal length. Basis with 1 setule on lateral margin. Intercoxal plate reduced. Endopod half as long as exopod, carrying 5 setae in all: First 2 segments lacking any armature; terminal segment with 1 lateral, 2 terminal and 2 medial setae. Exopod with 5 setae and 7 graded spines in all: First segment with 1 short spine and 1 seta respectively at outer and inner distal corners; second segment with 1 similar outer spine; third segment with 3 lateral and 2 terminal spines and 4 lateral setae. Spines feeble, blunt and graded in length. Setae all non-plumose except for the one on first exopod segment.

Third leg (Fig. 3, p) resembles second in constitution, though reduced in armature of rami: Third endopod segment and first exopod segment lacking 1 medial seta respectively. Thus, endopod with 4 setae and exopod with 4 setae and 7 spines.

Fourth leg (Fig. 3, q) smaller than preceding ones and more reduced in segmentation and armature, i. e., endopod 2-segmented, bearing 3 terminal short setae; exopod with 3 medial setae and 7 spines.

Fifth leg (Figs. 1, d and 3, s) a non-articulated scale-like structure divided into 2 pointed lobes. Outer lobe with 1 short distal seta and inner lobe with 1 similar one about middle of outer margin. Legs of both sides close to each other on midline and not articulated with sternal surface.

Caudal ramus (Fig. 3, r, s, t) as long as anal segment and about 2.3 times as long as its own width. Though difficult to differentiate its setal armature from general cuticular hairs covering surface, ramus appearing to be armed with 4 apical short setae and 2 similar ones on margins; one at about middle of outer margin and other at same level on dorsal side.

Remarks: This form has been recorded from many compound ascidians mainly of the orders Aplousobranchia and Stolidobranchia in various localities around Europe. 


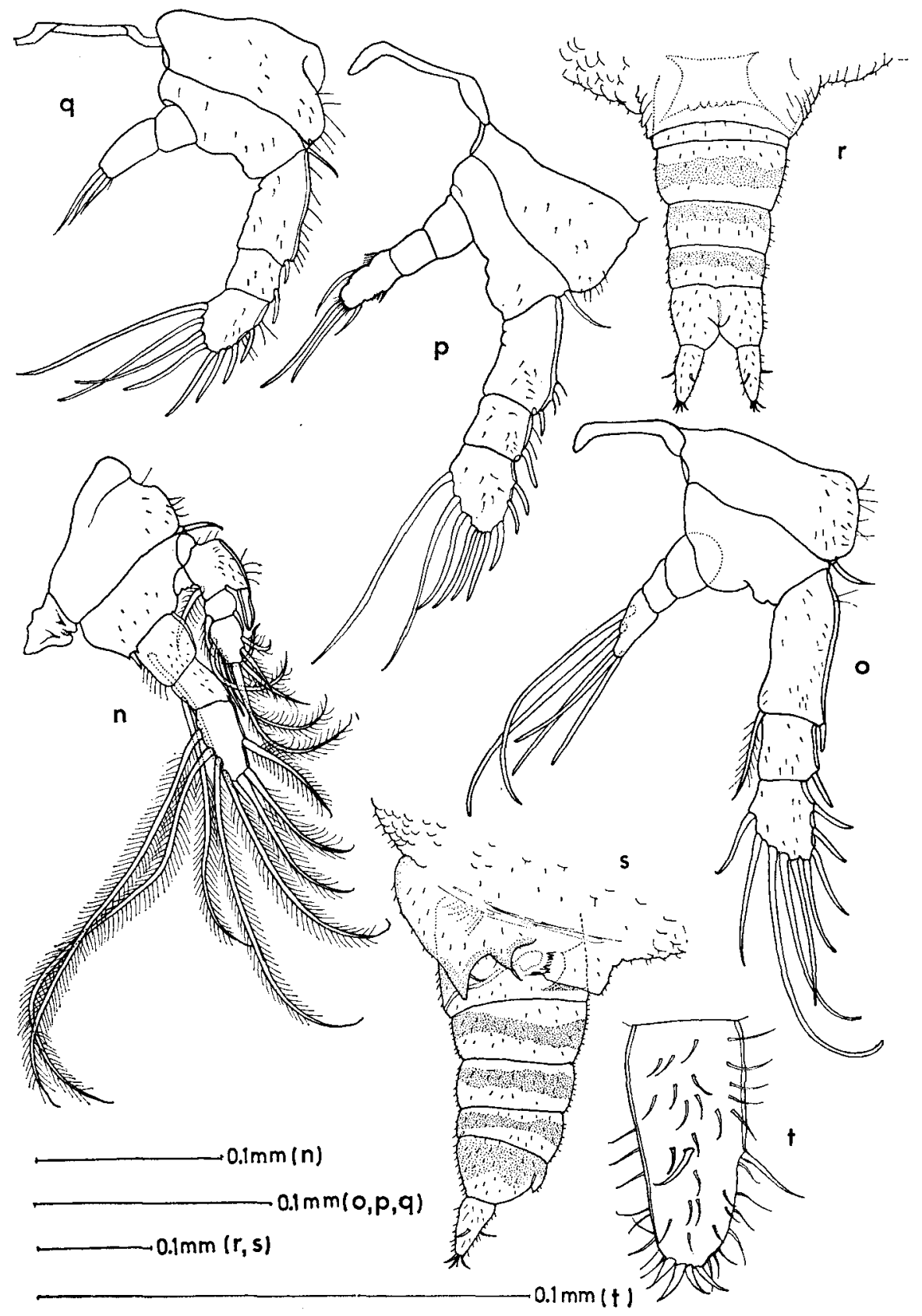

Fig. 3. Doroixys uncinata Kerschner, female: $n$, 1st leg, left, anterior view; o, 2nd leg, left, anterior view; p, 3rd leg, left, anterior view; q, 4th leg, left, anterior view; r, urosome, dorsal view; s, same, lateral view; $t$, caudal ramus, right, dorsal view. 
The present specimens from the Pacific are fundamentally the same as the European ones. But some minor differences are found between them: (1) in Pacific specimens the antenna is furnished with 2 additional setules at the apex near the claw; (2) the first leg has one more seta on the third endopod segment; (3) the second leg carries an additional seta on the first exopod segment; (4) the fifth leg bears an additional seta in its outer lobe; (5) the paragnaths are present; (6) the incubatory pouch tends to extend to the second metasomal segment. The last feature of the incubatory pouch is similar to that of $D$. minuta Sтоск, 1970 which is much smaller in size and lives in Didemnum from Puerto Rico.

\section{Prophioseides ampullacea n. sp.}

(Text-figs. 4-7; Pl. XIV, 4)

Specimens examined: From test of Diplosoma mitsukurii Ora (PL. XIV, Fig. 3), growing near base of Sargassum, Akkeshi Bay, 2-5 m deep, 5ㅇ (St. 1, October 14), 20 (St. 1, October 18), i. e., 25 females total, comprising 1 holotype and 24 paratypes.

Description: Female (Figs. 4-7 and PL. XIV, Fig. 4): This species (Fig. 4, a, b, c) has a characteristic ampulla-shaped body. Total length excluding caudal rami $2.96 \mathrm{~mm}$. Body divided into 3 divisions of cephalosome, metasome and urosome with proportional lengths, anterior to posterior, about 1:8.3: 1. Body color white, transparent, with reddish eye, yellow gut and bluish ova. Cephalosome (Figs. 4, e and $5, f$ ) relatively small, carrying appendages up to maxillipeds. Fore end prolonged ventrally into a large finger-shaped, apically rounded rostrum. Pleura of cephalosome inflated ventrally, encompassing oral field. Postero-dorsal part of cephalosome covered with characteristic sclerotized coating. Metasome divided into 2 regions: Anterior region narrow, flexible and vermiform, bearing first 3 pairs of legs; posterior region inflated into a globular part with width of $1.12 \mathrm{~mm}$, carrying fourth legs. Cephalosome plus whole metasome thus giving rise to an ampulla- or flask-like configuration. Articulations between limb-bearing segments (1st, 2nd, 3rd, 4th) discernible ventrally, while indicated only by undefined surface grooves dorsally. Intestine coiled, visible through body wall and more clearly by dissection. Narrow straight gut starting from mouth extends straight backward to join expanded intestinal coil, which, running from left to right, to end in narrow rectum opening at anus. Brood pouch lying dorsolateral to intestine. Oviduct of an inverted $u$-shape, containing a single layer of ova, and lying on either side of intestine. Globular expansion of last metasomal segment due to such disposition of digestive and genital systems. Fifth legs absent, but a pair of slit-like chitinous thickenings on last metasomal segment on either side of midventral line at its posterior third possibly representing their vestiges. These facts suggesting last expanded metasomal segment represents coalescence of fourth and fifth segments. Urosome (Fig. 7, t, u, v) abruptly constricted from metasome without 
a

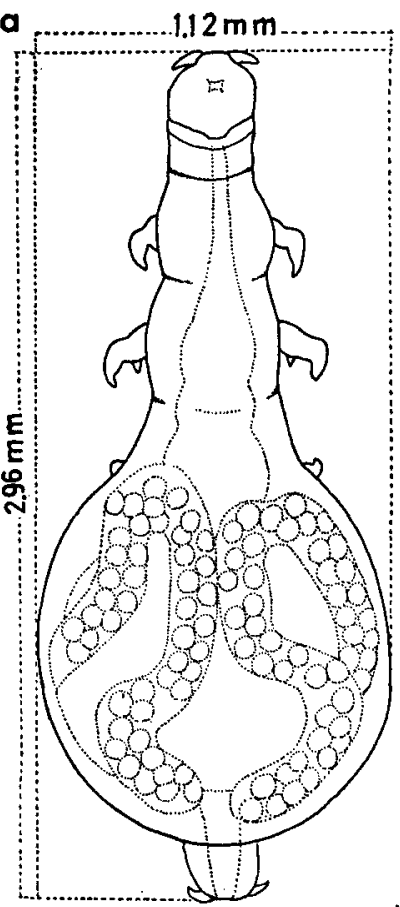

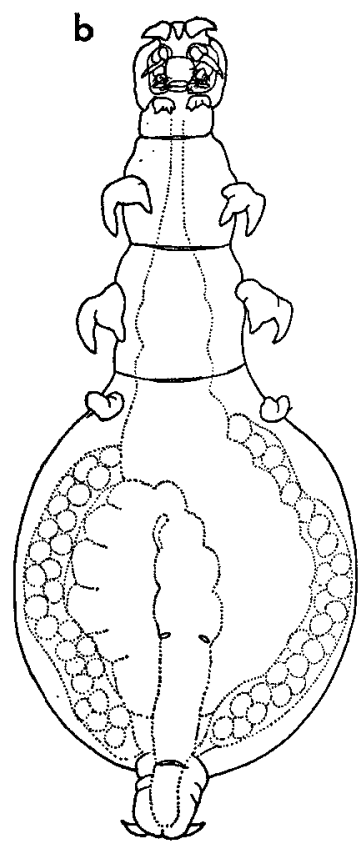
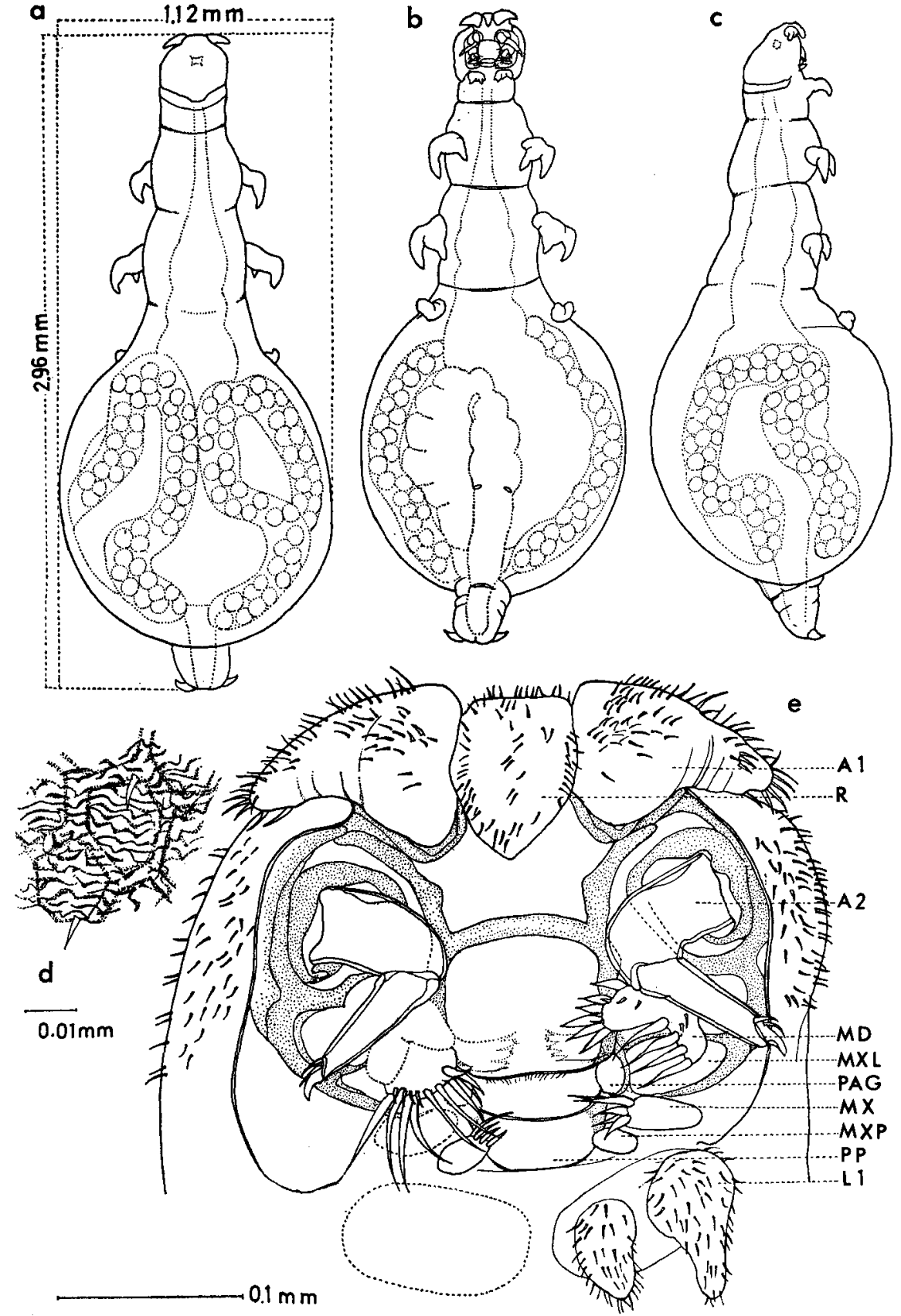

Fig. 4. Prophioseides ampullacea n. sp., female: a, dorsal view; b, same, ventral view; c, same, lateral view; $d$, integument of 4th metasomal segment; e, oral area. 
any distinct articulation. First segment coalesced anteriorly with metasome and delimited posteriorly with remaining undefined segmented urosome on ventral side. On dorsal side this segment covered by posterior extension of metasome which forms a lobe. Incubatory pouch opens at this extreme posterior limit of lobe. Under lobe urosomal segment shows a broad plate-like sclerotization which appears to be delimited from posterior urosomal segments on dorsal side. Vulval opening encircled by a small sclerotized girdle of inverted $u$-shape on mid-ventral region of first urosomal segment. Seminal tubes directed from vulva toward sides to reach seminal vesicles enclosed in this segment. Remaining urosomal region poorly defined into 2 segments, carrying caudal rami terminally. Anus opening mid-dorsally and subterminally, covered with small semicircular operculum. Entire body surface covered with minute hairs. Integument of last metasomal segment enclosing incubatory pouch with many characteristic sculptural features (Fig. 4, d).

Antennule (Fig. 5, g) a relatively large curved lobe, with several inconspicuous lines suggesting segments, broader basally and attenuated toward round tip. Armature probably consisting of many setae and a few aesthetes, though their number cannot be counted exactly among cuticular hairs covering surface.

Antenna (Fig. 5, h) robust, consisting of 2 subequal segments. Appendage heavily sclerotized, especially in basal segment, of which heavier sclerotization suggests segment originating in coalescence of 2 subsegments. First segment without armature. Second segment with 2 setules inserted halfway on outer margin and 1 stout claw and 2 setules at apex.

Labrum (Fig. 5, i) heavily sclerotized, wider than long, and hairy on margin. Inner surface furnished with transverse row of more than 30 teeth in a region displaced much internally from margin and with paired hair groups farther internally.

Mandible (Fig. 5, j, k) consisting of coxa, with long and heavily sclerotized coxal lamella, unarticulated basis and unimerous rami. Coxal lamella protruding medially beneath labrum and cut into 1 bifurcated distal spinule, array of 3 trilobate teeth and 2 proximal spinules, proximalmost of these having an accessory branch. Basis bearing 1 stout seta possibly indicating its distal medial extent. Exopod with 4 terminal setae. Endopod armed with 5 setae, comprising 3 medial and 2 terminal setae. All setae plumose. Besides these setae rami have some tiny hairs on outer surfaces.

Paragnath (Figs. 4, e and 5, 1) a heavily sclerotized forefinger-shaped lobe, with fine hairs on medial side, close to mouth, much medial to mouthparts and roughly opposite base of maxillule.

Maxillule (Fig. 6, m) bilobed. Inner lobe representing very possibly major endite and bearing 4 stout subequal setae ranging from medial to distal margins. Outer lobe probably formed by coalescence of exopod and endopod, bearing 3 lateral and 3 terminal setae accompanied at base of lateral setae by several hairs. All setae plumose.

Maxilla (Fig. 6, n) obscurely 5-segmented. Distal 4 segments more or less fused 


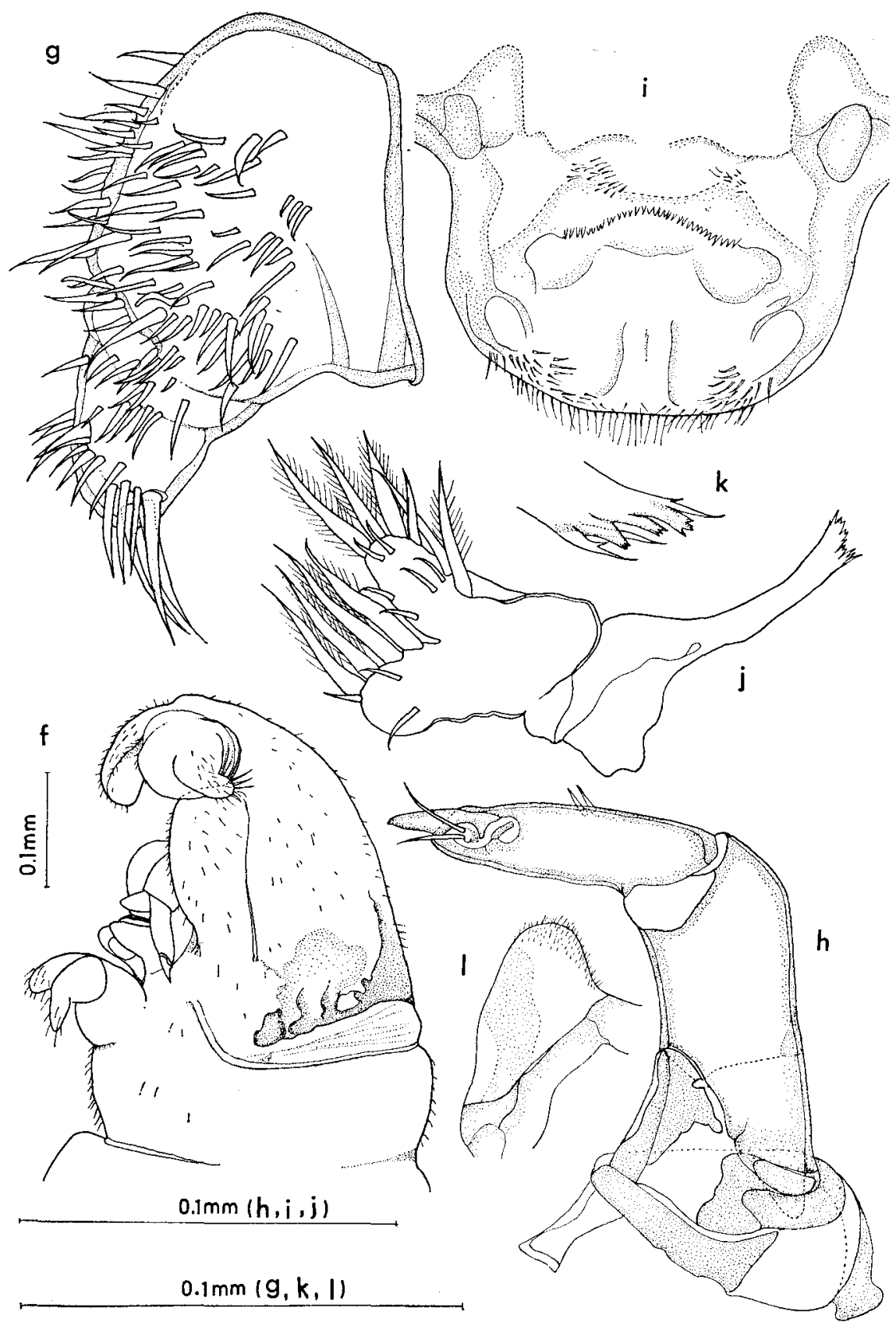

Fig. 5. Prophioseides ampullacea n. sp., female: f, cephalosome, lateral view; g, antennule; h, antenna; $i$, labrum, internal view; $j$, mandible, left, anterior view; $k$, same, masticatory plate; 1, paragnath, left. 
on their outer halves, differentiating into 2 or 3 segmental units. Basal segment broader toward base, with 2 stout plumose setae. Succeeding 3 segments each with 1 simple medial seta respectively. Terminal segment with 3 smaller setae at apex, one of them plumose.

Maxilliped (Fig. 6, o) an unsegmented lobe, twice as long as wide, bearing 6 finely plumose setae divided into 2 groups: Two setae terminally and 4 medially.

First leg (Fig. 6, p) consisting of an unsegmented broad protopod supporting 2 simple triangular rami. Leg standing vertically on sternal surface, bent backward at a right angle at about middle of each ramus. Members of either side separated from each other by a narrow space, but lacking intercoxal plate. Endopod ill-defined from protopod, with 1 finger-shaped barbed spine midway on medial margin. Exopod similar but a little longer, carrying 1 lateral seta at about proximal one-third on margin.

Second leg (Fig. 6, q) much larger than first, consisting of an unsegmented protopod and long triangular non-articulating rami. Legs of two sides widely separated from each other and without intercoxal plate. Rami bent at a right angle as in preceding legs. Cuticular hairs heavier on rami than on protopod. No particular ornamentation observed.

Third leg (Fig. 6, r) resembling preceding ones in structure and armature.

Fourth leg (Fig. 7, s) much smaller than second and third, consisting of unsegmented protopod and 2 small, anteriorly directed rami. Endopod a simple squat lobe fused at its base with similar-shaped exopod. Both heavily sclerotized in marginal portions. A single conspicuous plumose seta inserted on exopod in middle of lateral margin. Surfaces covered with cuticular hairs.

Fifth legs (Fig. 7, t, w, x) represented by a pair of small elliptical, strongly sclerotized rings of integument located at posterior one-third of ventral side of last metasomal segment. Many wrinkles of integument surrounding these vestigial legs.

Caudal ramus (Fig. 7, y) conical, divergently issuing from end of urosome. Aside from general covering of cuticular hairs, ornamentation consisting of 1 lateral, 1 dorsal and 4 terminal setae.

Remarks: Four species belonging to Prophioseides, P. abdominalis, P. biramus, $P$. delamarei and $P$. diplosomae, have been recorded from compound ascidians of the families Synoicidae and Didemnidae of the order Aplousobranchia in European waters and the Red Sea. They are vermiform in configuration, which has constituted one of the important characters of the genus. P. brevis living in a solitary ascidian chiefly differs from them in its shorter, thicker and non-vermiform body. P. ampullacea n. sp. is distinguishable from either vermiform or non-vermiform species by the characteristic ampulla-shaped body. The species seems, however, to correspond to the vermiform type by having a vermiform anterior body comprising cephalosome plus first three metasomal segments.

Though different from $P$. diplosomae in several points the present species has a 


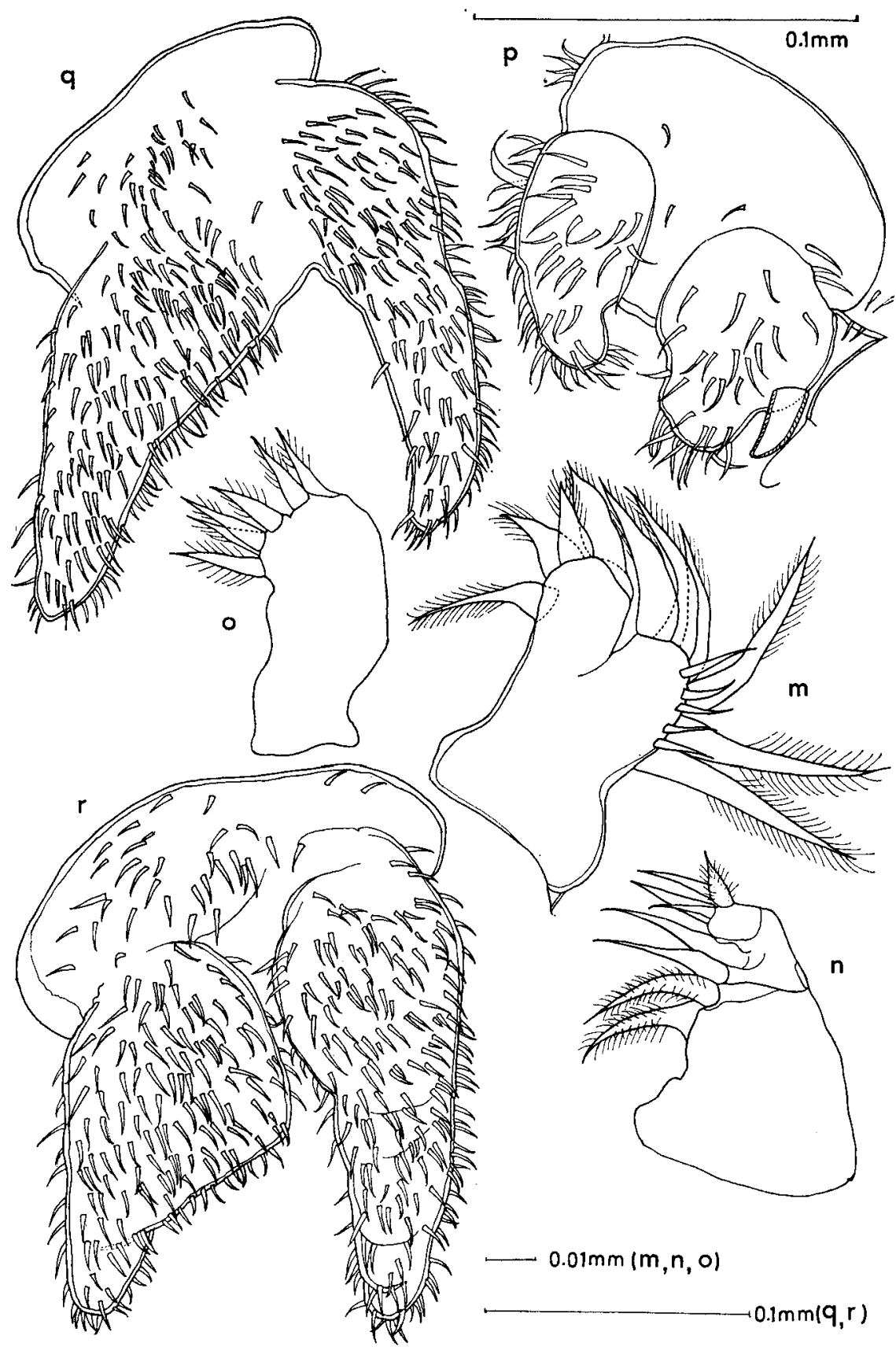

Fig. 6. Prophioseides ampullacea n. sp., female: m, maxillule, right, anterior view; $\mathrm{n}$, maxilla, right, anterior view; o, maxilliped, right, anterior view; $\mathrm{p}$, Ist leg, right, anterior view; q, 2nd leg, left, anterior view; r, 3rd leg, left, anterior view. 


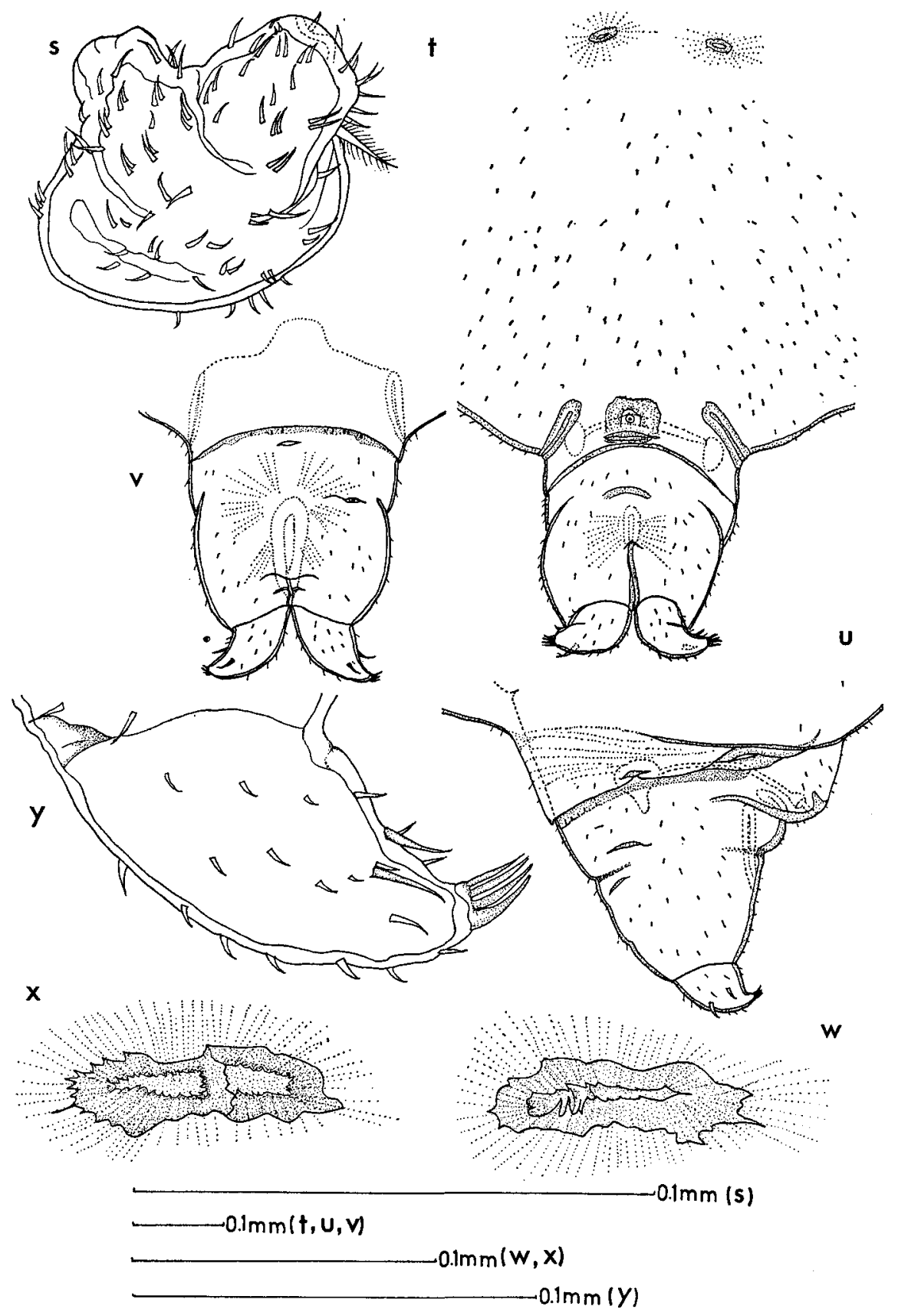

Fig. 7. Prophioseides ampullacea n. sp., female: s, 4th leg, left, posterior view; t, urosome, ventral view; $u$, same, lateral view; v, same, dorsal view; $w$, vestige of 5 th leg, right, external view; $x$, same, internal view; $y$, caudal ramus, dorsal view. 
closer relationship to this than to other species in morphological and ecological points: (1) the antennule is a tapering lobe having certain indications of segments; (2) the first leg consists of a plate-like structure with two lobes, the inner member of which bears a heavy spine; (3) the second leg has two triangular lobes; (4) the urosome is ill-defined in segmentation and carries diverging caudal rami; (5) both the species occur in Diplosoma, of the family Didemnidae. The features of appendages enumerated below may serve to differentiate the present species from $P$. diplosomae as well as other members of the genus: (1) the paragnaths are present; (2) the third leg is welldeveloped, having large triangular rami; (3) the fourth leg is relatively small, but has characteristically sclerotized rami; (4) the fifth leg is reduced to a vestige discernible on the last metasomal segment.

One adult and 6 copepodid males in the present collection will be reported in a future paper.

\section{Demoixys fusiforma n. sp.}

(Text-figs. 8-10; Pl. XIV, 6)

Specimens examined: From test of Distaplia dubia (Ока) (PL. XIV, Fig. 5) attached to bases of Sargassum, Akkeshi Bay, 2-5 m deep, 10우 (St. 2, October 14), 30 ㅇ (St. 3, October 22), i. e., 40 females total, inclusive of 1 holotype and 39 paratypes.

Description: Female (Figs. 8-10 and PL. XIV, Fig. 6): Body (Fig. 8, a, b, c) relatively large, straight and fusiform. Three divisions of body, cephalosome, metasome and urosome, distinct, with their proportional lengths: $0.7: 6: 1$. General surface covered with tiny hairs. Total length (including caudal rami) $2.8 \mathrm{~mm}$. Most inflated portion at about middle of body (fourth metasomal segment) $1.2 \mathrm{~mm}$ wide. Body color whitish transparent, eye reddish and gut brownish. Gut straight, with many constrictions. Cephalosome with appendages up to maxillipeds. Rostrum (Figs. 8, $\mathrm{d}$ and $9, \mathrm{~g}$ ) a mid-ventrally directed tiny lobe. Lateral parts of cephalosome probably representing pleura, which are divided into anterior and posterior halves and inflated ventrally, encircling oral area from both sides. Dorsal surface of cephalosome strongly sclerotized. Metasome 4-segmented; articulations more or less distinct on mid-ventral surface and a little behind each pair of thoracic legs, whereas indicated by one or two cuticle grooves on expanded dorsal side. Pinkish transparent ova found in inverted $u$-shaped oviducts lying in entire metasome. Urosome (Figs. 8, e and 10, t, u) 4-segmented: Ventral side of each segment covered with characteristic sclerotized coating. First segment clearly articulated with last metasomal segment on ventral side. The latter carrying triangular fifth legs, tips of which reach terminal margin of first urosomal segment. Genital apparatus consisting of vulva and diverging seminal tubes, which lie ventrally and extend to seminal vesicles in first urosomal segment. 


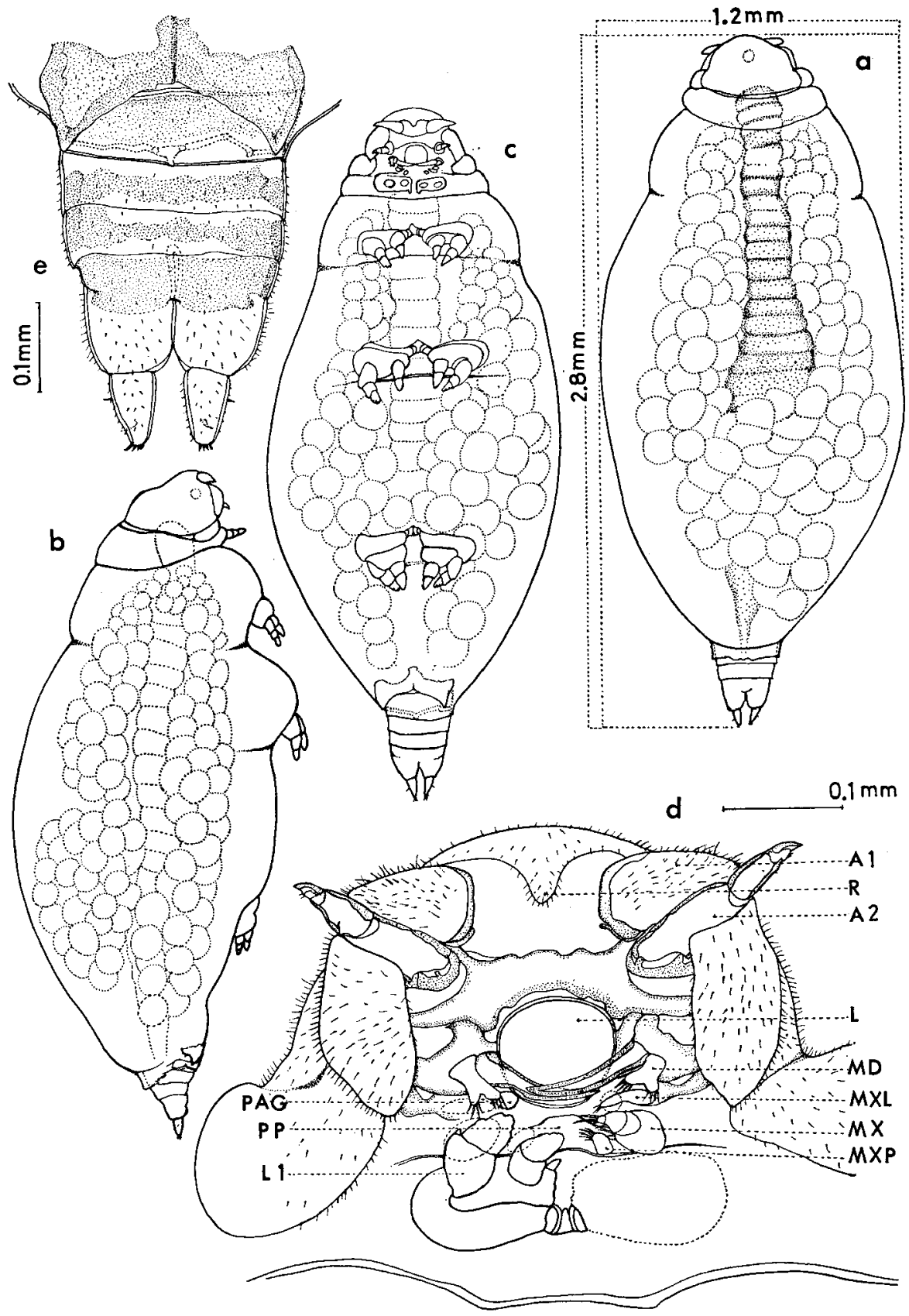

Fig. 8. Demoixys fusiforma n. sp., female: a, dorsal view; b, same, lateral view; c, same, ventral view; $d$, oral area; e, urosome, ventral view. 


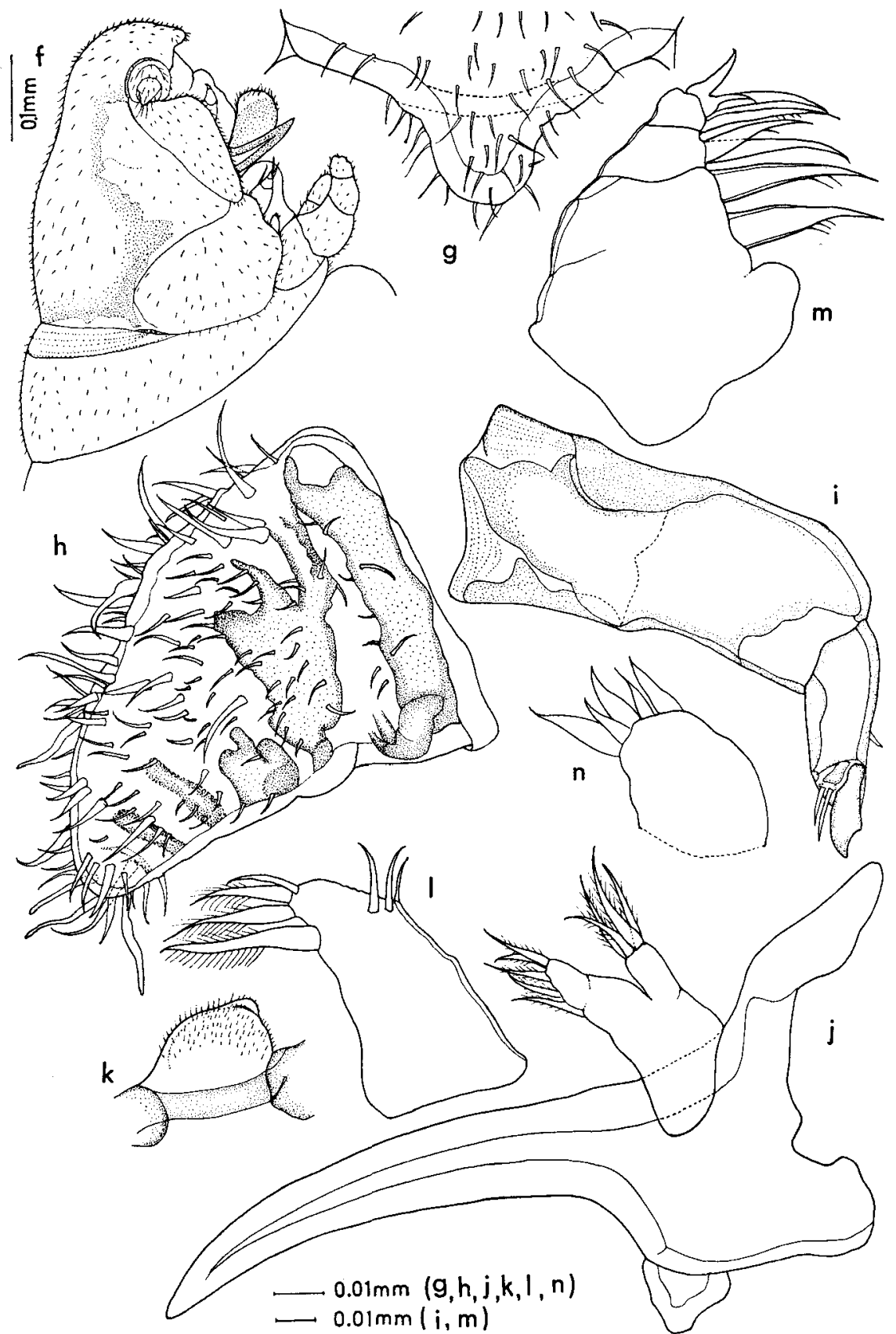

Fig. 9. Demoixys fusiforma n. sp., female: f, cephalosome, lateral view; g, rostrum; h, antennule; $i$, antenna; $j$, mandible, right, anterior view; $k$, paragnath, left, postero-lateral view; 1 , maxillule, left, posterior view; $m$, maxilla, right, posterior view; $n$, maxilliped, left, posterior view. 
Metasome extending backward over distal margin of second urosomal segment on dorsal side where incubatory cavity opens. This posterior elongation of metasome coalesced with first and second urosomal segments on their lateral sides. Caudal rami relatively small and terminal. Anal operculum a small sclerotized plate interposed between bifurcation of terminal segment on upper side.

Antennule (Fig. 9, h) a simple tapering lobe with round tip. Armature of many setae and a few aesthetes, but hardly distinguishable from hairs covering general surface. Several characteristic sclerotized coatings covering this appendage.

Antenna (Fig. 9, i) 2-segmented, with basal segment twice as long as terminal segment. Sclerotization of basal segment characteristic, particularly heavy on posterior side, suggesting a division into sub-segments. Terminal segment furnished with 1 setule at distal third of outer margin and with 1 claw at apex accompanied by another set of 2 setules.

Labrum (Figs. 8, d and 9, f) pushed up by protruding teeth of mandibles anteriorly.

Mandible (Figs. 8, d and 9, j) consisting of a large, strongly chitinized coxa and a small flap. Masticatory lamella of coxa transformed into a lanceolate process, overlapping corresponding member of opposite side on midventral side. Flap composed of non-articulated basis, endopod and exopod. Basis with 1 seta, possibly at junction with rami. Endopod and exopod portions of flap subequal in length, both ending in 4 setae. All setae finely plumose.

Paragnath (Figs. 8, d and 9, k) a small sclerotized mammiform process, covered with fine hairs, located at base of maxillule, much medial to bases of mouthpart series and close to mouth.

Maxillule (Figs. 8, d and 9, 1) reduced to a simple elliptical lobe with length twice as long as greatest width, and tipped with 4 graded plumose setae on medial side subterminally and 3 shorter simple setae midway on lateral margin.

Maxilla (Fig. 9, m) massive, broader at base and 4-segmented. Basal segment occupying two thirds of total length, probably including 3 endites, one non-setose and 2 others each with 1 stout barbed seta respectively. Second segment wider than long, having 2 stout, subequal setae. Third segment with 1 stout barbed seta, and fourth the smallest of all with 1 long and 2 short, non-hairy setae.

Maxilliped (Fig. 9, n) reduced to a simple lobe bearing 5 non-hairy terminal setae.

First leg (Fig. 10, o) consisting of broad 2-segmented protopod and 2-segmented unequal rami. Intercoxal plate subtriangular. Basis with 1 stout serrated spine at inner distal angle. Endopod three-fifths as long as exopod: Terminal segment with 3 protuberances disposed at apex, on middle of outer border and on subterminal inner border. Each protuberance (Fig. 10, p) covered with a few rows of spinules on its posterior side. Exopod with 1 spinulated protuberance surmounted by 1 blunt spine near outer distal angle of first segment, and with 1 lateral, 1 subterminal and 1 


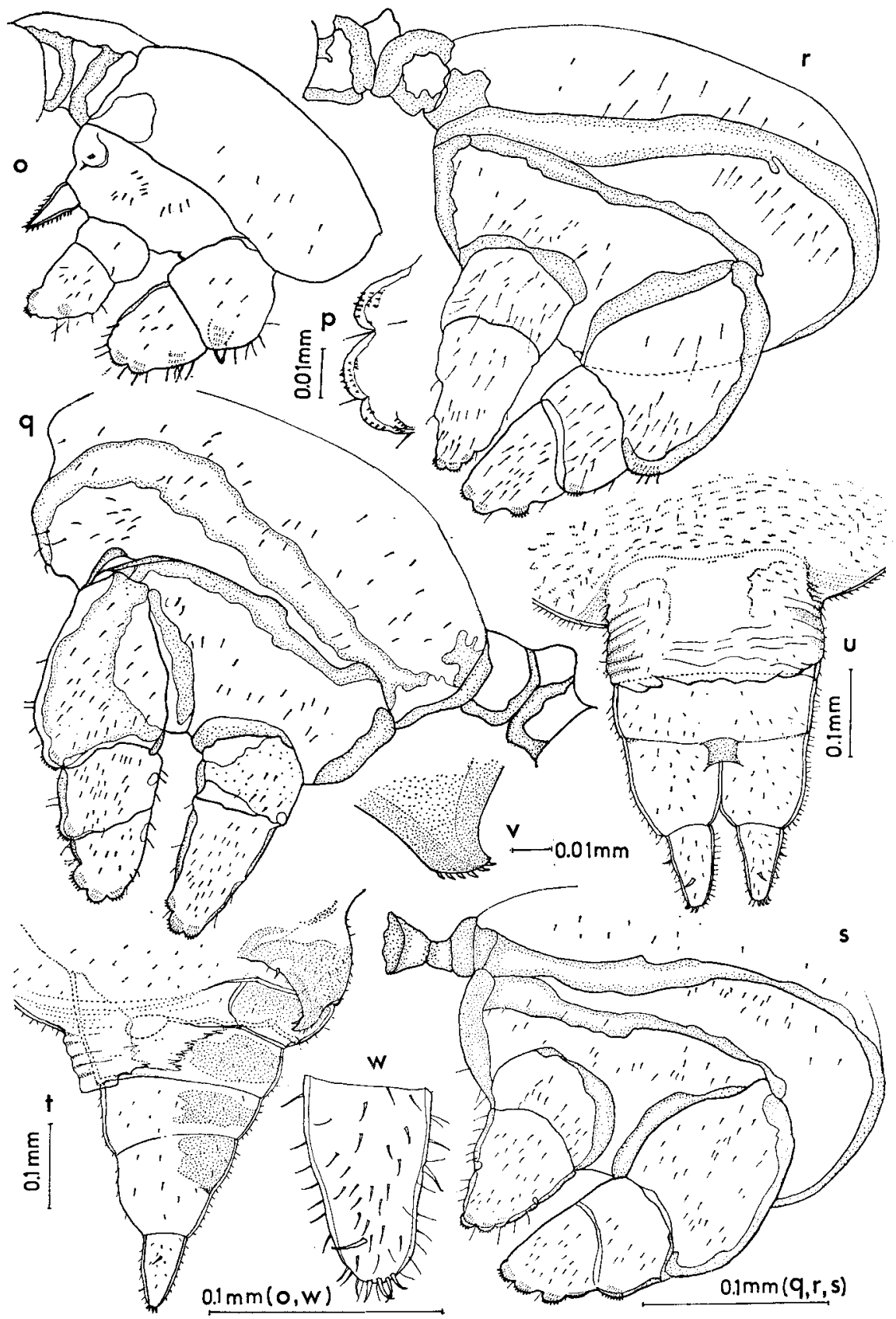

Fig. 10. Demoixys fusiforma n. sp., female: $\mathrm{o}$, lst leg, left, anterior view; $\mathrm{p}$, tip of 2 nd endopod, posterior view; q, 2nd leg, right, anterior view; r, 3rd leg, left, anterior view; s, 4th leg, left, anterior view; t, urosome, lateral view; $u$, same, dorsal view; $v$, 5 th leg, terminal end, posterior view; $w$, caudal ramus, right, dorsal view. 
terminal protuberance on second segment. Entire leg hairy on surface.

Second leg (Fig. 10, q) with 2-segmented protopod and endopod and 3-segmented exopod. Intercoxal plate trapezoidal. Endopod two thirds as long as exopod, having terminal array of 3 protuberances. Exopod armed with 5 protuberances, i. e., 1 at outer distal corner of first 2 segments respectively and remaining 3 on third segment terminally. Entire leg characteristically sclerotized.

Third leg (Fig. 10, r) much resembling second in constitution and armature.

Fourth leg (Fig. 10, s) similar to but slightly smaller than third leg except for decrease of 1 protuberance from proximal exopod segment.

Fifth leg (Figs. 8, e and 10, t, v) a sclerotized triangular lobe united mid-ventrally with corresponding member of other side to form a characteristic bilobed plate. Each leg curved inwards, denticulated at apex and armed on lateral margin with 1 subterminal and 1 subbasal setule.

Caudal rami (Fig. 10, w) about 1.7 times as long as wide, and armed with 6 setae: 1 at proximal third of lateral margin, 1 at distal fourth of dorsal margin and 4 at apex.

Remarks: Four species of the genus Demoixys have hitherto been known. Three of them, $D$. chattoni, $D$. dialepta (from the Mediterranean Sea) and $D$. abdominalis (from the Red Sea) are found in ascidians of the family Didemnidae while the remaining, D. affinis (from the Indian Ocean) was reported from an octocoral. The present species lives in an ascidian belonging to the family Polycitoridae.

This species is assigned to Demoixys in spite of perplexing features that deviate from the definition of the genus in having more reduced head appendages and more developed thoracic ones. The degree of reduction of the head appendages, involving 2-segmented antennae in this species, resembles the case in Prophioseides, while the grade of modification of the thoracic legs from first to fifth approaches Demoixys in which all the appendages are relatively developed though the two genera are very similar to each other. However, the highly characteristic following features make this fall within the limits of Demoixys: (1) the body is fusiform (vermiform in the Prophioseides species living in compound ascidians); (2) the first to fourth legs are clearly represented and with segmented rami (greatly reduced in Prophioseides); (3) the triangular fifth legs are united together to form a bilobed mid-ventral plate (lacking or rudimentary in Prophioseides). Moreover, D. fusiforma n. sp. is distinguished from the other four species of Demoixys by the above-mentioned inconsistent features.

The genus Demoixys was originally established on the basis of the Mediterranean species and at the same time it was remarked that the generic concept is a very broad one (Illg and Dudley, 1961, p. 74). In fact it has become broader than before after the well-segmented antennule was described in $D$. abdominalis and $D$. affinis, as the appendage is a reduced simple lobe in the original definition. Furthermore, it is said that the last two species tend to bridge the gap between Demoixys and Mesoixys (Stock and Humes, 1970, p. 210). Mesoixys and D. affinis seem to approach Doroixys 
due to the presence of a pointed process at the postero-lateral corner on either side of cephalosome.

Such interrelation of features among the genera, Demoixys, Mesoixys and Doroixys, is also noticed among these 3 genera, the present species and Prophioseides, e. g., (1) a simple lanceolate coxa of the mandible exists in the present species, Mesoixys and $P$. brevis, (2) a segmented abdomen is found in the present species, $D$. abdominalis, D. affinis, Mesoixys and Doroixys. As regards articulation between metasome and urosome, morphological structures of the opening of incubatory cavity and setal armature of the caudal rami, etc., this species is anatomically identical to the 2 species, $D$. uncinata and $P$. ampullacea $\mathbf{n}$. sp. which are described in this paper.

ILLG and DudLey (1965, p. 441) suggested that more extensive study of the genera comprising Demoixys, Doroixys, Mesoixys and Prophioseides, which have reduced appendages and modified bodies, will prove the possibility of combining them into a single genus. Therefore the present species is put within the genus Demoixys for the present time instead of establishing a special genus for it.

\section{LITERATURE GITED}

Bocquet, C. \& J. H. Stock, 1961. Copépodes parasites d'Invertébrés des côtes de France. XIII. Les genres Ophioseidimorphes de la famille des Notodelphyidae. Proc. Koninkl. Nederl. Akad. Wetenschappen, Amsterdam, (C) 64(2): 212-226, figs. 1-22.

Brément, E., 1909. Contribution à l'étude des Copépodes ascidicoles du Golf du Lion. Arch. Zool. Expér. Gén., (5) 1: lxi-lxxxix, figs. 1-14.

Cand, E., 1892. Les Copépodes du Boulonnais: Morphologie, embryologie, taxonomie. Trav. Lab. Zool. Marit. Wimereux-Ambleteuse, 6: 1-354, pls. 1-30.

Chatton, E. \& E. Brément, 1911. Sur un ascidicole nouveau du genre Ophioseides Hesse, Ophioseides abdominalis, parasite des aplidiens. Bull. Soc. Zool. France, 36: 29-33, 1 fig.

_ \& - 1915a. Brementia balneolensis n. g., n. sp., nouveau copépode ascidicole incubateur, parasite des Leptoclinum. Bull. Soc. Zool. France, 40: 129-134, figs. 1-2.

$-\&-1915 \mathrm{~b}$. Sur un noubeau copépode ascidicole incubateur Ooneides amela n. g., n. sp., parasite des Leptoclinum. Bull. Soc. Zool. France, 40: 135-143, figs. 1-4.

Dudley, P. L. \& D. N. Solomon, 1966. Pythodelphys acruris, a new genus and species of copepoda (Notodelphyidae) from the Pacific Ocean. Crustaceana, 11 (3): 314-320, figs. 1-2.

GiARd, A., 1873. Contribution à l'histoire naturelle des Synascidies. Arch. Zool. Exp. Gén., (1) $2: 481$ 514, pl. 19.

ILLG, P. L., 1958. North American copepods of the family Notodelphyidae. Proc. U.S. Nation. Mus., $107(3390): 463-649$, figs. 1-19.

Illg, P. L. \& P. L. Dudley, 1961. Notodelphyid copepods from Banyuls-sur-Mer. Vie et Milieu. Suppl., 12: 1-126, figs. 1-41.

$\& \_$, 1965. Notodelphyid copepods from the vicinity of Naples. Pubbl. staz. zool. Napoli, 34: 373-451, figs. 1-21.

Kerschner, L., 1879. Uber zwei neue Notodelphyiden nebst Bemerkungen über einige Organisationsverhältnisse dieser Familie. Denkschr. math.-naturw. Cl. K. Akad. Wiss., Wien, 41: 155-196, pls. $1-6$.

Lafargue, F. \& L. Laubier, 1968a. Cochlodelphys delamarei, noubeau genre et nouvelle espèce de Copépode Notodelphyidae en Méditerranée occidentale. C. R. Acad. Sc. Paris, 267: 1375-1378. \& $-1968 \mathrm{~b}$. Sicyodelphys bocqueti, nouveau genre et nouvelle espèce de Copèpode 
Notodelphyidae en Méditerranée occidentale. Ibid., 267: 2163-2166.

Schelenberg, A., 1922. Neue Notodelphyiden des Berliner und Hamburger Museums mit einer Utbersicht der ascidienbewohnenden Gattungen und Arten. Mitt. Zool. Mus. Berlin, 10: 219-274, figs. 1-43; 277-298, figs. 1-12.

Sтоск, J. H., 1967. Report on the Notodelphyidae (Copepoda, Cyclopoida) of the Israel South Red Sea Expedition. Bull. Sea Fish. Res. Stat. Haifa, 27: 1-126.

- 1970. Notodelphyidae and Botryllophilidae (Copepoda) from the West Indies. Stud. Fau. Curaçao \& Caribbean Isls., 34 (123): 1-45, figs. 1-21.

Stock, J. H. \& A. G. Humes, 1970. On four New Notodelphyid Copepods, associated with an Octocoral, Parerythropodium fulvum (FonsKÅL), in Madagascar. Zool. Anz. 184: 194-212, figs. 1-10.

\section{EXPLANATION OF PLATE XIV}

Fig. 1. Amaroucium constellatum VerRILL

Fig. 2. Doroixys uncinata Kerschner, lateral view.

Fig. 3. Diplosoma mitsukurii OKA

Fig. 4. Prophioseides ampullacea n. sp., dorsal view.

Fig. 5. Distaplia dubia (OKA)

Fig. 6. Demoixys fusiforma n. sp., lateral view. 